\title{
Hubungan Pengetahuan dan Sikap dengan Perilaku Orangtua tentang Diare pada Balita di RSCM Kiara
}

Arini Ika Hapsari, Hartono Gunardi*

Program Studi Pendidikan Dokter Fakultas Kedokteran Universitas Indonesia

${ }^{*}$ Departemen Ilmu Kesehatan Anak Fakultas Kedokteran Universitas Indonesia Rumah Sakit Dr. Cipto Mangunkusumo, Jakarta

Latar belakang. Diare masih merupakan penyebab utama kesakitan dan kematian pada balita di Indonesia. Tingkat pengetahuan, sikap, dan perilaku orangtua tentang diare dapat berpengaruh terhadap angka kejadian diare pada balita.

Tujuan. Mengetahui tingkat pengetahuan, sikap, dan perilaku tentang diare, serta hubungan antar variabel tersebut.

Metode. Penelitian potong lintang ini dilakukan di RSCM Kiara pada September 2015. Data diperoleh dari wawancara dengan orangtua berdasarkan kuesioner. Analisis statistik dilakukan dengan Chi-square atau uji Fischer.

Hasil. Di antara 102 subyek, terdapat 101 (99\%) subjek memiliki tingkat pengetahuan baik, 55 (54\%) subjek memiliki sikap positif, dan 55 (54\%) memiliki perilaku baik tentang diare. Tidak ada hubungan bermakna antara tingkat pengetahuan dengan perilaku $(\mathrm{p}=0,353)$ dan antara sikap dengan perilaku orangtua tentang diare. $(\mathrm{p}=0,290)$.

Kesimpulan. Hampir seluruh orangtua memiliki tingkat pengetahuan yang baik, dan mayoritas subyek mempunyai sikap dan perilaku yang baik tentang diare. Pengetahuan dan sikap orangtua tidak berhubungan dengan perilaku tentang diare pada anak. Sari Pediatri 2018;19(6):316-20

Kata kunci: pengetahuan, sikap, perilaku, orangtua, diare, balita

\section{The Association between Parental Knowledge and Attitude towards Their Behavior regarding Diarrhea in under-five Children at RSCM-Kiara}

Arini Ika Hapsari, Hartono Gunardi*

Background. In Indonesia, diarrhea is one of the main causes of children morbidity and mortality. Parental knowledge, attitude, and behavior towards diarrhea are probably associated with diarrhea incidence in children.

Objective. This study aims to explore the parental knowledge, attitude, behavior toward diarrhea and the association between those variables.

Methods. A cross-sectional study was conducted in RSCM - Kiara in September 2015. Chi-square and Fischer test was used to analyze the association.

Result. Among 102 subjects, 101 subjects (99\%) had good knowledge, 55 subjects (53.9\%) had positive attitudes, and 55 subjects $(53.9 \%)$ had good behavior regarding children diarrhea. This study confirms that almost all of the parents had a good knowledge, yet almost half of them still had unfavorable attitude and behavior.

Conclusion. There was no significant association between parental knowledge with behavior $(\mathrm{p}=0.353)$ and between parental attitudes with behavior $(\mathrm{p}=0.29)$ toward children diarrhea. Sari Pediatri 2018;19(6):316-20

Keywords: knowledge, attitude, behavior, parents, diarrhea

Alamat korespondensi: DR. Dr. Hartono Gunardi, SpA(K). Departemen Ilmu Kesehatan Anak Fakultas Kedokteran Universitas Indonesia Rumah Sakit Dr. Cipto Mangunkusumo, Jakarta. E-mail: ariniika24@gmail.com 
Arini Ika Hapsari dkk: Hubungan pengetahuan dan sikap dengan perilaku orangtua tentang diare pada balita

$\mathrm{D}$ iare merupakan penyebab kematian kedua terbanyak pada anak balita setelah pneumonia. ${ }^{1}$ Menurut WHO (2013), setiap tahunnya sekitar 1,7 milyar kasus diare pada balita dan menyebabkan kematian sebanyak 760.000 balita di seluruh dunia. ${ }^{2}$ Di Indonesia, angka kejadian diare mencapai 411/1000 penduduk pada tahun 2010. ${ }^{3}$ Data Riset Kesehatan Dasar (Riskesdas) tahun 2013 menunjukkan insiden diare di Indonesia masih tinggi, yaitu sebesar 3,5\% pada seluruh usia dengan insiden tertinggi pada kelompok usia balita $(6,7 \%){ }^{4}$

Orangtua sebagai salah satu orang yang paling dekat dengan anak memiliki peran penting dalam pengendalian diare anak, baik dalam hal pencegahan maupun tatalaksana awal. Pengetahuan, sikap, dan perilaku yang baik dari orangtua dalam pencegahan dan manajemen diare pada anak tentu berperan dalam menurunkan angka kesakitan dan kematian akibat diare pada anak. Penelitian ini bertujuan mengetahui pengetahuan, sikap dan perilaku orangtua tentang diare pada anak serta hubungan antara pendidikan dan sikap dengan perilaku orangtua tentang diare pada anak balita.

\section{Metode}

Penelitian potong lintang dilakukan pada orangtua balita yang datang berobat ke poliklinik anak RSCM Kiara selama September 2015. Data diperoleh dari wawancara orangtua berdasarkan kuesioner. Pemilihan sampel dilakukan dengan teknik consecutive sampling. Subyek adalah orangtua dengan kriteria inklusi, yaitu memiliki bayi berusia 2 bulan sampai 5 tahun yang tidak sakit berat. Kriteria eksklusi adalah orangtua yang tidak bersedia mengikuti penelitian atau tidak dapat membaca dan menulis: Subjek yang tidak mengisi kuesioner dengan lengkap dianggap sebagai drop out. Kuesioner berisi total (jumlah) pertanyaan pilihan ganda yang terbagi menjadi 3 bagian, yaitu pengetahuan (10 pertanyaan), sikap ( 9 pertanyaan), dan perilaku (9 pertanyaan). Pengetahuan dikategorikan menjadi pengetahuan baik ( $\geq 80 \%$ total skor), cukup ( $\geq 60 \%-79 \%$ total skor), dan kurang $(<60 \%) .^{5}$ Sikap subjek diukur melalui 9 pertanyaan pilihan ganda terkait sikap mengenai diare Pilihan jawaban pertanyaan dikategorikan menjadi sangat setuju (SS), setuju (S), tidak setuju (TS), dan sangat tidak setuju (STS). Untuk pertanyaan positif, jawaban sangat setuju (SS) diberikan skor 5, jawaban setuju (S) diberikan skor 3, jawaban tidak setuju (TS) diberikan skor 1, dan jawaban sangat tidak setuju (STS) diberikan skor 1. Untuk pertanyaan negatif berlaku sebaliknya.

Sikap dikategorikan menjadi sikap mendukung atau favourable bila nilai sikap lebih besar dari rerata total skor sikap seluruh subjek dan kurang mendukung atau unfavourable bila nilai sikap lebih kecil dari rerata total skor seluruh subjek. ${ }^{6}$ Perilaku subyek diukur melalui 9 pertanyaan pilihan ganda terkait perilaku mengenai diare. Perilaku subyek dikegorikan menjadi perilaku baik apabila skor perilaku lebih besar dari nilai rata-rata total skor perilaku seluruh subjek dan perilaku kurang baik apabila skor perilaku < nilai rata-rata total skor perilaku seluruh subjek. ${ }^{6}$

Data dianalisis secara statistik menggunakan aplikasi SPSS 21.0 untuk Windows. Analisis menggunakan uji Chi-square atau Fisher untuk data kategorik tidak berpasangan, dengan tingkat kemaknaan ( $\alpha$ ) 5\% dan interval kepercayaan (IK) 95\%.

\section{Hasil}

Terdapat 102 subjek yang memenuhi kriteria inklusi dan seluruh subyek adalah ibu (Tabel 1). Mayoritas subjek berasal dari golongan usia 31-40 tahun (52,9\%) berpendidikan SLTA (48\%) dan merupakan ibu rumah tangga $(68,6 \%)$.

Tabel 1. Karakteristik sosiodemografi subjek

\begin{tabular}{lcc}
\hline Sosiodemografi & Jumlah & $(\%)$ \\
\hline Usia (tahun) & & \\
$21-30$ & 37 & 36,3 \\
$31-40$ & 54 & 52,9 \\
$41-50$ & 10 & 9,8 \\
$51-60$ & 1 & 1 \\
Pendidikan & & \\
Perguruan Tinggi dan Akademi & 10 & 9,8 \\
SLTA & 49 & 48 \\
SLTP & 10 & 9,8 \\
SD & 6 & 5,9 \\
Tidak diketahui & 27 & 28,5 \\
Pekerjaan & & \\
Bekerja & 5 & 4,9 \\
Tidak bekerja & 70 & 68,6 \\
Tidak diketahui & 27 & 26,5 \\
\hline
\end{tabular}


Rerata skor pengetahuan subjek tentang diare adalah 41,9 (SD 5,2) dari skor maksimal 50 dengan rentang 30-50. Rerata skor sikap subjek adalah 34,67 (SD 6,3) dari skor maksimal 45 dengan rentang 23-45. Rerata skor perilaku subjek adalah 33,57 (SD 4,4) dari skor maksimal 45 dengan rentang 21-43 (Tabel 2).

Hasil analisis bivariat menggunakan uji statistik Chi-square menyatakan bahwa tidak terdapat hubungan yang bermakna secara statistik antara tingkat pengetahuan dan sikap dengan perilaku subjek tentang diare pada anak $(\mathrm{p}>0,05)$ (Tabel 3).

Tabel 2. Karakteristik pengetahuan, sikap, dan perilaku subjek

\begin{tabular}{lcc}
\hline Variabel & Jumlah & $(\%)$ \\
\hline Pengetahuan & & \\
$\quad$ Baik & 101 & 99 \\
$\quad$ Kurang Baik & 1 & 1 \\
Sikap & & \\
$\quad$ Positif (favourable) & 55 & 53,9 \\
$\quad$ Negatif (unfavourable) & 47 & 46,1 \\
Perilaku & & \\
$\quad$ Baik & 55 & 53,9 \\
$\quad$ Kurang Baik & 47 & 46,1 \\
\hline
\end{tabular}

Tabel 3. Hubungan Pengetahuan dan Sikap dengan Perilaku Subjek

\begin{tabular}{lccc}
\hline \multirow{2}{*}{ Variabel } & \multicolumn{2}{c}{ Perilaku } & \multirow{2}{*}{$\mathrm{p}$} \\
\cline { 2 - 3 } & Baik & Kurang Baik & \\
\hline Pengetahuan & 54 & 47 & 0,353 \\
$\quad$ Baik - Cukup & 1 & 0 & \\
$\quad$ Kurang & & & \\
Sikap & 27 & 28 & 0,29 \\
$\quad$ Positif (favourable) & 28 & 15 & \\
$\quad$ Negatif (unfavourable) & 28 & & \\
\hline
\end{tabular}

\section{Pembahasan}

Diare masih merupakan masalah kesehatan di Indonesia. Menurut data Riskesdas 2013, DKI Jakarta termasuk dalam provinsi dengan insiden tertinggi selain Aceh, Papua, Sulawesi Selatan, dan Banten. ${ }^{4}$ Data dari Ditjen P2LP tahun 2016 melaporkan bahwa dari 5.405.235 perkiraan kasus diare yang ditangani di fasilitas kesehatan, hanya 4.017.861 kasus (74,3\%) yang secara nyata ditangani fasilitas kesehatan di seluruh Indonesia. ${ }^{7}$ Orangtua yang mencari pertolongan ke fasilitas kesehatan dipengaruhi oleh pengetahuan, sikap dan perilaku individu atau keluarga yang bersangkutan. Pengobatan diare balita dipengaruhi oleh pengetahuan, sikap dan perilaku orangtua..$^{8-10}$

Tingkat pengetahuan orangtua tentang diare pada anak hampir seluruhnya baik. Hal tersebut dapat dikaitkan dengan mayoritas subjek yang tergolong usia dewasa muda dan berpendidikan cukup baik. Sejalan dengan penelitian Amare $\mathrm{dkk}^{11}$ terhadap $846 \mathrm{ibu}$ di Ethiopia Utara yang melaporkan bahwa mayoritas $(63,6 \%)$ ibu memiliki pengetahuan yang baik tentang diare. Hal yang sama juga ditemukan Supono dkk ${ }^{12}$ terhadap 175 subjek di Bekasi yang melaporkan bahwa 59,4\% ibu memiliki tingkat pengetahuan diare yang baik. Hal tersebut dapat disimpulkan bahwa secara umum mayoritas orangtua telah mempunyai pengetahuan yang baik tentang diare.

Subjek berusia di atas 30 tahun cenderung memiliki skor pengetahuan yang lebih tinggi. Hal yang sama juga ditemukan pada penelitian di Kashan, Iran, ${ }^{13}$ bahwa ibu dengan usia yang lebih tua dan memiliki $\geq 3$ anak memiliki skor pengetahuan yang lebih tinggi. Hal tersebut berkaitan dengan pengalaman terdahulu ibu dalam manajemen diare.

Selain usia yang lebih matang, skor pengetahuan yang lebih tinggi juga ditemui pada subjek orantua dengan tingkat pendidikan di atas SLTA. Sesuai dengan hasil penelitian di Kecamatan Bekasi Utara yang melaporkan bahwa pendidikan dianggap sebagai faktor yang berkaitan dengan pengetahuan ibu. Hal tersebut berimplikasi pada setiap kegiatan program peningkatan pengetahuan untuk menekan angka diare. Dengan kampanye maupun penyuluhan, di samping isi pesan, faktor pendidikan adalah kelompok sasaran yang perlu menjadi perhatian. ${ }^{12}$

Perbedaan tingkat pengetahuan pada suatu populasi dengan populasi lainnya dapat dipengaruhi oleh faktor internal (tingkat pendidikan, pekerjaan, usia) dan faktor eksternal (sumber informasi, pajanan media, budaya). ${ }^{14}$ Pada umumnya, tingkat pendidikan formal seseorang cenderung berhubungan positif dengan tingkat pengetahuannya. Selain itu, pendidikan juga dapat memengaruhi perilaku dan pola hidup seseorang ${ }^{14}$ Selain faktor pendidikan, faktor usia dan pekerjaan juga dapat memengaruhi tingkat pengetahuan seseorang.

Subjek dengan sikap positif (favourable) sedikit lebih banyak daripada subjek dengan sikap negatif (unfavourable). Hal tersebut sesuai dengan penelitian 
Merga dkk, ${ }^{15}$ di Assosa, Ethiopia Barat, yang melaporkan $62,9 \%$ subjek mempunyai sikap positif tentang penyebab, transmisi, dan pencegahan diare. Namun, penelitian yang dilakukan oleh Supono $\mathrm{dkk}^{12}$ menunjukkan hal yang berbeda. Supono melaporkan hanya $45,1 \%$ ibu yang beranggapan bahwa diare merupakan penyakit serius. Hal tersebut mungkin disebabkan peran variabel perancu, seperti pengetahuan, pengalaman kontak dengan diare dan kepercayaan subyek. ${ }^{12}$

Subjek dengan kategori usia lebih dari 30 tahun dan subjek yang berprofesi sebagai ibu rumah tangga cenderung memiliki skor sikap yang lebih tinggi dibandingkan yang lain. Adapun perbedaan tingkat pendidikan tidak memiliki pengaruh terhadap skor sikap subjek.

Sikap seseorang terhadap masalah tertentu dipengaruhi oleh berbagai faktor, di antaranya pengalaman pribadi, pengaruh orang yang dianggap penting, kebudayaan, media massa, lembaga pendidikan dan lembaga agama, dan faktor emosional. ${ }^{16}$

Subjek berperilaku baik sedikit lebih banyak $(53,9 \%)$ daripada subjek berperilaku kurang baik. Hal hampir serupa ditemukan Amare $\mathrm{dkk}^{13}$ yang melaporkan subjek dengan perilaku baik sedikit lebih mendominasi $(54,1 \%)$.

Subjek dengan tingkat pendidikan setara SLTA atau di atasnya memiliki skor perilaku yang lebih tinggi. Perilaku yang lebih baik ini juga ditemukan pada subjek dengan kategori usia 41-50 tahun dan pada subjek yang berprofesi sebagai ibu rumah tangga. ${ }^{13} \mathrm{Pada}$ penelitian yang dilakukan di Ethiopia Utara ditemukan bahwa ibu yang memiliki tingkat pengetahuan yang rendah memiliki 25,5 kali kemungkinan untuk berperilaku buruk dibandingkan dengan ibu dengan tingkat pengetahuan yang baik. Tingkat pendidikan juga berperan terhadap perilaku ibu yang tidak dapat baca tulis, berisiko 4,7 kali berperilaku buruk dalam pencegahan dan tatalaksana diare pada balita. ${ }^{11}$

Berdasarkan hasil analisis bivariat tidak ditemukan adanya hubungan antara pengetahuan dan sikap terhadap perilaku. Hal tersebut dapat disebabkan oleh adanya pengaruh faktor lain, seperti lingkungan, norma, dan sosiodemografi. Teori 'kognitif sosial' menyebutkan bahwa perilaku tidak hanya dipengaruhi faktor personal dalam diri seseorang, seperti motivasi, tujuan, dan kemauan, tetapi juga turut dipengaruhi oleh lingkungannya. Selain itu, terdapat variabel lain yang turut memengaruhi, yaitu efikasi diri, ekspektasi hasil, kontrol diri, kemampuan emosional, pembelajaran melalui observasi, dan motivasi/ penguatan. Peran pengetahuan untuk meningkatkan motivasi dan efikasi diri. ${ }^{16}$

Teori 'perilaku terencana' (planned behavior) yang dikemukakan oleh Ajzen, ${ }^{17}$ menyatakan bahwa perilaku tergantung pada tujuan untuk melakukan perilaku. Intensi ditentukan oleh sikap (kepercayaan dan nilai tentang luaran perilaku) dan norma subjektif (keyakinan orang lain berpikir tentang apa yang harus dilakukan) serta kontrol perilaku individu.

\section{Kesimpulan}

Orangtua yang berobat ke RSCM Kiara hampir seluruhnya memiliki pengetahuan yang baik, dan lebih dari setengah telah memiliki sikap dan perilaku yang positif. Pengetahuan dan sikap orangtua tidak berhubungan dengan perilaku tentang diare pada anak. Untuk meningkatkan sikap dan perilaku, orangtua perlu menghayati pengetahuan dan menjalankan pengetahuan yang telah dimiliki dalam mencegah maupun pengobatan awal diare pada anak. Selain itu, peningkatan sikap dan perilaku orangtua dapat dibantu oleh dokter, perawat, dan bidan dengan melakukan penyuluhan interaktif untuk membantu proses internalisasi dan timbulnya perilaku positif.

\section{Daftar pustaka}

1. World Health Organization. Diarrhoea: why children are still dying and what can be done. Geneva: WHO; 2009. h.1-14.

2. World Health Organization. Diarrhoeal diseases. Factsheet No 330, April 2013. Diakses 22 April 2017. Didapat dari: http:// www.who.int/mediacentrelfactsheets/fs330/en/.

3. Kementerian Kesehatan RI. Buletin Jendela Data dan Informasi Kesehatan: Situasi Diare di Indonesia. Jakarta: Kementerian Kesehatan RI; 2011.h.3-25.

4. Badan Penelitian dan Pengembangan Kesehatan. Riset Kesehatan Dasar 2013. Jakarta: Kementerian Kesehatan RI; 2013.h. 72-6.

5. Surjono E. Fimansyah A. Batubara JRL. Knowledge of pediatrician on gastroesophageal reflux/gastriesophageal reflux disease in children: a preliminary study. Ped Indo 2010;50:336-9.

6. Fuge TG, Ayanto SY, Gurmamo FL. Assessment of knowledge, attitude and practice about malaria and ITNs utilization among pregnant women in Shashogo District, Southern 
Ethiopia. Malaria Journal 2015;14:235-43.

7. Kementerian Kesehatan RI. Profil Kesehatan Indonesia 2015. Diakses 5 Maret 2017. Didapat dari: http://www.depkes.go.id/ resources/download/pusdatin/profil-kesehatan-indonesialprofilkesehatan-Indonesia-2015.pdf.

8. Rahmah NLM, Luthviatin N, Purianty M. Hubungan pengetahuan dan sikap ibu balita tentang diare terhadap tindakan pemberian cairan rehidrasi pada anak balita diare, studi kasus di Wilayah Kerja Puskesmas Patrang Kabupaten Jember [skripsi]. Fakultas Kesehatan Masyarakat Universitas Jember, 2013. Diakses 21 Maret 2017. Didapat dari: http://repository. unej.ac.id/bitstream/handle/123456789/1779/Nur\%20Laily\% 20MR\%20-\%20082110101089_1.pdf? sequence $=1$.

9. Djaja S, Ariawan I, Afifah T. Perilaku pencarian pengobatan diare pada balita. Bul Penel Kesehatan 2002;30:22-30.

10. Nasrin D, Wu Y, Blackwelder WC, Kotloff KL, dkk. Health care seeking for childhood diarrhea in developing countries: evidence from seven sites in Africa and Asia. Am J Trop Med Hyg 2013;89(1 Suppl):3-12.

11. Amare D, Dereje B, Kassie B, Ayele A, dkk. Maternal knowledge and practice towards diarrhoea management in under five children in Fenote Selam Town, West Gojjam Zone, Amhara Regional State, Northwest Ethiopia. J Infect Dis Ther 2014;2:6-16

12. Supono, J. Faktor prediksi persepsi ibu tentang diare pada balita. Jurnal Kesehatan Masyarakat Nasional 2008;2:179-85

13. Ghasemi AA, Talebian A, Alavi NM, dkk. Knowledge of mothers in management of diarrhea in under-five children, in Kashan, Iran. Nursing and Midwifery Studies 2013; 1:158-62.

14. Notoadmodjo, S. Pendidikan dan perilaku kesehatan. dalam: kesehatan masyarakat: ilmu dan seni. Jakarta: PT Rineka Cipta;2007.h.143-7.

15. Merga N, Alemayehu T. Knowledge, perception, and management skills of mothers with under five children about diarrhoreal disase in indigenous and resettlement communities in Assosa District, Western Ethiopia. J Health Popul Nutr 2015;33:20-30.

16. The World Bank. Theories of behaviour change. Diakses 26 November 2015. Didapat dari: $\underline{h} t t p s: / / s i t e r e s o u r c e s . w o r l d b a n k$. org/EXTGOVACC/Resources/BehaviorChangeweb.pdf.

17. Ajzen I. Theory of planned behavior. Organ Behav Hum Decis Process 1991;50:179-211. 